Vol-3, Issue-1, 2019 (IJEBAR)

ISSN: 2614-1280

http://www.jurnal.stie-aas/ijebar

\title{
THE EFFECTS OF FINANCIAL RATIO, LOCAL SIZE AND LOCAL STATUS ON FINANCIAL DISTRESS
}

\author{
Novica Indriaty ${ }^{1}$, Doddy Setiawan ${ }^{2}$, Yuwita Ariessa Pravasanti ${ }^{3}$ \\ ${ }^{1,2}$ Faculty of Economics and Business, Sebelas Maret University \\ ${ }^{3}$ STIE AAS Surakarta \\ ${ }^{1}$ Email : novicaindri@gmail.com \\ ${ }^{2}$ Email : doddy.setiawan@gmail.com \\ ${ }^{3}$ Email : yuwita.akuntansi@gmail.com
}

\begin{abstract}
This study was aimed to examine the effects of financial ratio empirically, local size and local status on financial distress. The status of financial distress is the condition of the inability of the local government to repay the loan principal and the loan interest. The population of this study include local governments in Indonesia that publish Report on Local Government Finances in 2008-2014. Samples were selected based on purposive sampling method and obtained 641 as research observation. With logistic regression, this study found that financial ratio included current ratio $(C R)$, debt to equity ratio $(D / E)$, operating revenues to total revenues ratio $(O R / T R)$, return on assets ratio $(R O A)$, return on equity ratio (ROE), and macro-economic variables were local size and local status have a significant effect on financial distress.
\end{abstract}

Keywords : Financial Distress, Financial Ratio, Local Size, Local Status, Logistic Regression, Report on Local Government Finances

\section{INTRODUCTION}

After the economic crisis that hit Indonesia, regional autonomy was born as an effort to improve people's welfare. Regional autonomy is a good opportunity for local governments to explore its ability to implement the rights of local authority and freedom to be creative in developing regions by referring to the Law. However, the successes of the implementation of regional autonomy need to be questioned. Reporting from the UNIKOM scientific magazine, there are eight problems found in the practice of implementing regional autonomy. Two of these problems are financial balancing and Local Government Budget (Surtikanti, 2013). Wasteful behavior that deplete local governments that more than a half of budget only to finance the employees expenditure will deliver them to the brink of bankruptcy. The results of the FITRA analysis on the Local Government Budget in 2011, there were 124 regions where the expenditure burden of employees exceeded $60 \%$ and 16 of them reached $70 \%$. Whereas, in 2012 there were 291 regions that projected employee expenditure of more than 50 percent. From the 291 regions, there are 11 local governments that have employee expenditure of 70 percent and above with the highest value of 76.7 percent as occupied by the City of Langsa (source: Summary of Local Government Budget in 2012, Directorate-General of Regional 
Fiscal Balance). Employees' expenditure that absorbs too much regional budget will automatically reduce capital expenditure. A spokesman for the Ministry of Home Affairs said that capital expenditure, especially for infrastructure nationally, had only reached 21.70 percent and had not been in line with the national target. This condition shows that the function of the local government to provide quality public service fulfillment as mandated by regional autonomy cannot be realized yet.

According to Cohen et al (2012) local governments are said to have good financial performance if they can fulfill financial obligations and service obligations to the community, now and in the future. However, when the local government is unable to provide public services to the community according to establish quality standards, the government is indicated to experience financial distress (Jones and Walker, 2007; ACIR, 1985).

Some of the previous empirical researcher have developed financial distress indicators. Financial ratio is the most widely used analytical techniques in predicting financial distress as done by Beaver (1966), Plat and Plat (2002), and Amendola et. al (2015). An accurate financial distress prediction models had an important influence on various corporate stakeholders in the decision-making process and can be used as an early warning regarding the financial condition of corporate distress, so anticipatory actions can be taken against conditions that lead to bankruptcy (Xie, Luo, and Yu, 2011; Almilia and Kristijadi, 2003). However, the application of the private sector financial distress model in the public sector is not suitable. This is because of the intrinsic character of each so that the interpretation of the values of financial ratios and expected quantities is different in the two sectors. For example, the existence of high ROA and ROCE values indicates the efficiency of a private company, but not for a local government because of its non-profit character (Cohen et al., 2012).

In the public sector, financial distress is a serious problem because if it is not addressed it will lead to regional bankruptcy. This study will develop financial distress prediction models using financial ratio and non-financial factor as indicators that has been done by previous researchers (John and Walker 2007; Cohen, 2008; Sutaryo, 2009; Trussel and Patrick, 2009; Cohen et al, 2012).

Sutaryo (2009) uses eighteen ratios to predict the probability of local governments experiencing financial distress with the binary logistic regression method. These ratios consist of financial performance ratios, financial position ratios, efficiency ratios and debt ratios. The results of the study show empirical evidence that in one year predictive testing after the publication of government financial reports, information in ROA, POSGW, CLGW, LQ, $\mathrm{CL}$ and LTDA ratios can be used to predict the probability of financial distress of local governments in Indonesia. Meanwhile, in the testing two years after the issuance of the regional government financial report proves that the ratio of PERGW, LCO, LTDA and DTR can be used to predict the probability of financial distress of local governments in Indonesia. These results indicate that the information in the financial statements of local governments in 
Vol-3, Issue-1, 2019 (IJEBAR)

\section{ISSN: 2614-1280}

http://www.jurnal.stie-aas/ijebar

Indonesia has predictive value so that it is relevant to use in decision making.

Trussel and Patrick

investigate financial risk factors related to fiscal distress of regional governments in Pennsylvania. This study hypothesizes that fiscal distress is positively related to revenue concentration and debt usage, negatively related to administrative costs and entity resources. In their analysis they used panel data with years of observation from 1998 to 2005. The number of samples after being selected was 11,544 local governments consisting of 1,025 local governments (8.9\% of the total) classified as fiscal distress and 10,579 local governments $(91,1 \%$ of total) classified as not fiscal distress. This study found evidence that the decline in intergovernmental revenue and increased administrative expenditure had the greatest influence in reducing the possibility of fiscal distress. The results of this study provide important insights about the possibility of fiscal distress and strategies to reduce fiscal distress that are useful for central government officials and local governments in detecting and preventing fiscal distress.

Cohen et al. (2012) built a model to evaluate the financial viability of city governments in Greece. The evaluation model was developed on the basis of multicriteria decision making methodology and financial information from accrual financial data from 360 Greek city governments for 2007. An additional sample of 100 city governments in 2009 to examine the effect of the financial crisis in Greece on financial performance. In the analysis six financial ratios were selected, namely $\mathrm{L} / \mathrm{A}$, $\mathrm{R} / \mathrm{L}, \mathrm{STL} / \mathrm{R}, \mathrm{OE} / \mathrm{R}, \mathrm{S} / \mathrm{P}$ and R/P according to financial criteria in the public sector. The model succeeded in classifying distress cities according to the benchmark set by the central government in 2010. The practical implication of this research is that the developed model is easy to implement and can be used for benchmarking purposes and provides early signs of distress to some stakeholders that are useful in decision making.

Jones and Walker (2007) examine various financial and non-financial measures in predicting local government distress in Australia. There are 4 (four) categories of explanatory variables namely council characteristic (such as size, regional status, number of staff); local service delivery variables (such as garbage services); infrastructure variables (such as estimation of development costs and infrastructure maintenance costs) and financial variables (proxied by financial ratios such as operating cash flow, cash position, liquidity and working capital, rate of return, financial structure, and debt repayment ability).

Related to local government finance, if the budget for Local Government Budget is limited, the local government can make regional loans to cover financing expenses so that services to the community increase. Regional loans are regulated in Government Regulation No. 30 of 2011.Based on these regulations, regional loans can be submitted to the central government if the local government can meet the stipulated requirements, namely the value of a Debt Service Coverage Ratio (DSCR) of at least 2.5. If an area has a DSCR value smaller than 2.5 , it is not permitted to make a regional loan because it is feared that it will experience difficulties in repaying the loan principal and interest. The condition of this 
difficulty is used as a condition of financial distress in the local government in the study.

Based on the results of previous studies, the authors are motivated to do research whether financial ratios and nonfinancial factors able to predict the financial distress of the local government. It needs to be examined because by knowing early on financial distress, local governments can take measures in anticipation of conditions that lead to bankruptcy. Differences of this study with previous studies are :

1) This study predicts financial distress in all local governments in Indonesia with a span of 7 years starting in 2008-2014.

2) The independent variable is not only focus on financial ratios, but also on non-financial factors such as local government size and local government status.

3) The Data analysis is logistic regression with the help of computer software for Eviews version 9 statistics.

\section{LITERATURE REVIEW AND DEVELOPMENT OF HYPOTHESIS}

\subsection{Literature Review}

a. Financial Distress

Financial distress is a condition that occurs before bankruptcy. In the private sector this condition has long been a concern of the government and investment groups. Therefore, financial distress models need to be developed so that actions can be taken to anticipate conditions that lead to bankruptcy. Xie et. al (2011), Habib et. al (2013), Platt and Platt (2002) define financial distress as a condition in which a company has difficulty to pay financial obligations to creditors, is in trouble with operational activities and decreases financial performance significantly and continuously so that it can lead to bankruptcy and financial losses for investors and creditors. In the public sector, Jones and Walker (2007) define financial distress as the inability of local governments to provide services to the public in accordance with established quality standards. This is due to the unavailability of funds to be invested in the infrastructure used in service provision so that this condition indicates that the government is experiencing financial difficulties.

Meanwhile, Sutaryo (2009) defines financial distress as the inability of local governments to repay both loan principal and loan interest. This definition refers to Government Regulation No.30 of 2011 concerning regional loans. The indicated ability is stated in the Debt Service Coverage Ratio (DSCR). Government Regulation No. 30 of 2011 in articles 15 and 16 states that local governments can make regional loans if they have a DSCR level of at least 2.5 (two point five). For local governments that are not able to reach the DSCR level, they are not allowed to make regional loans on the grounds to avoid difficulties in repaying both the principal and the interest of loan. If the local government experiences such difficulties (has a DSCR level of <2.5), it can be stated in the status of financial distress.

\section{b. Financial Ratio Analysis}

Ratio analysis is another way to present information from financial statements by expressing relationships between selected financial statement data. This relationship is expressed in terms of 
percentage, level, or simple proportion (Kieso et al. 2008: 222). Hanafi and Halim (2016: 74) classify ratio analysis into five categories, namely: liquidity ratio, activity ratio, solvency ratio, profitability ratio, and market ratio. The fifth ratio is to see the prospects and risks of the company in the future. Prospect factors in these ratios will affect investor expectations of the company in the future. In the public sector, the use of ratio analysis has not been done so much that in theory there is no unanimous agreement regarding the name and rules of measurement.

\subsection{Development of Hypotheses}

In predicting financial distress, the indicators that are often used are financial ratios of financial statements such as liquidity ratio, capital structure ratio, performance ratio, profitability ratio, and growth ratio (Cohen, 2008; Sutaryo, 2009; Trussel and Patrick, 2009; Cohen et al , 2012; Liao and Liu, 2014). Debt is often associated with financial distress. In the public sector, government debt is the most important part of funding (Sutaryo et al, 2012). Based on government regulation No. 30 of 2011 concerning regional loans, local governments can make loans to the central government or third parties. Sutaryo (2009) states that if debt is carried out at the central government, the interest and terms of return are carried out flexibly in the sense that it can be negotiated. However, if loans are made to third parties (such as banks), the treatment of government debt is the same as loans to the private sector.

One of the indicator of the occurrence of financial distress is a large amount of debt (Pasaribu, 2008). Debt can be used as a determination of liquidity ratios and capital structure ratios. Current ratio (CR) is a liquidity ratio that measures the ability of an entity to pay short-term liabilities. When the current ratio is low, it will have an impact on cash flow so that to cover regional operational costs, a larger number of short-term loans is needed and will affect financial distress. Cohen (2008) assessed the current ratio as a ratio that measures the ability of local governments to maintain financial position. This is because the current ratio that's very high and very low indicates financial operational problems. Almilia and Kristijadi (2003) prove that liquidity ratios have a significant effect in determining a company's financial distress.

The capital structure ratio expressed by the debt to equity ratio (D/E) in government entities is used to measure the ratio of the amount of debt to equity funds. This ratio shows how much equity (net worth) of local government is in fulfilling local government obligations in the form of short-term debt and long-term debt. The higher the debt that is owned, the higher the rate of debt repayment and the risk to the financial condition of the local government so that it can affect financial distress.

Research in the public sector, especially government entities that use debt proportions, was conducted by Cohen (2008) with the result that high and low liquidity is a good indicator of financial management and influences the financial performance of local governments in Greece. Sutaryo et al. $(2009,2012)$ use the current ratio, current liquidity government wealth (CLGW), current liquidity fund (CLFUND), liquidity (LQ), current liquidity 
Vol-3, Issue-1, 2019 (IJEBAR)

\section{ISSN: 2614-1280}

http://www.jurnal.stie-aas/ijebar

(CL), long term debt to total assets (LTDA) and debt to revenue (DTR ) as a debt ratio in predicting financial distress. The results show that information in the ratio of government debt except $\mathrm{CL}_{\mathrm{FUND}}$ can be used as a tool to predict financial distress.

In addition, the financial condition of local governments can also be influenced by the ratio of financial performance (performance ratio). This ratio measures the efficiency of an entity which is achieving maximum output with limited use of inputs (Sutaryo et al, 2012). Cohen (2008) uses the operating revenue to total revenue ratio (OR/TR) which describes the efficiency of government entities. The OR/TR ratio is a comparison between the amount of operating income and the total regional income. A high OR / TR ratio indicates that local governments are able to generate high operating income so that they can increase the amount of regional income without having to depend on the central government budget in the form of subsidies or transfer funds. Thus, the local government can be stated in an efficient condition and affect the financial condition of the local government.

In the public sector, profit is not the main goal. However, some studies using profitability ratios measuring the financial condition of local government as did Cohen (2008) and Sutaryo el al (2012). Profitability ratio is a comparison of the use of profits with entity resources (assets or equity). In non-profit oriented government organizations, the profitability ratio is adjusted by replacing profit (loss) with a surplus (deficit) on the government budget. A high surplus deficit indicates that the performance of the local government budget is not good enough. When the surplus value is high, the local government is considered unsuccessful in implementing the work program so that the established budget is not absorbed properly. While the budget deficit shows that regional income cannot cover the amount of regional expenditure. This certainly will affect the availability of government funds and the ability of local governments to pay the principal and interest of loans (Sutaryo et al, 2012).

Several studies have proven the ability of profitability ratios in predicting financial distress of local governments. Cohen (2008) uses return on equity (ROE), return on assets (ROA) and profit margin in its influence on the financial performance of local governments in Greece. Meanwhile, Liaou and Liu (2014) use return on assets (ROA) in controlling the relationship between local fiscal distress and investment efficiency of Local Government Owned Enterprises in China. This study uses return on assets and return on equity as a proxy for profitability ratios as used in the research of Cohen (2008) and Sutaryo (2009).

The last factor that can affect financial conditions is the growth ratio. This ratio measures how much the ability of local governments to maintain and increase the success they have achieved from the period to the next. Knowledgeable growth for each of these components of income and expenditure of resources can be used to evaluate the potential that need attention (Halim, 2007: 241). Trussel and Patrick (2009) calculate changes in total income from year to year (GROWTH) as a measure of changes in entity resources. The results showed that the GROWTH ratio had a significant effect on fiscal distress. 


\section{ISSN: 2614-1280}

http://www.jurnal.stie-aas/ijebar

This study does not only use financial ratios as variables that influence financial distress. However, it also considers macro-economic factors, namely the local size and local status. The local size is proxied by the population. Cohen (2008) proves that the population influences the financial performance of local governments. This research predicts that regional governments that have large populations will experience financial distress.

The local status in this study is the area resulting from expansion and nonexpansion. According to Law No. 32 of 2004, regional expansion basically aims to improve public services in order to accelerate the realization of public welfare. However, the expansion process often lead to regional instability and lack of attention to aspects of the region's ability to be expanded (Surtikanti, 2013). When viewed from the side of regional finance, new regions formed through local government policies show relatively less optimal performance compared to control areas. This is due to a number of problems such as greater fiscal dependence in the newly created regions, low income optimization and economic contributions, and low share of capital expenditure allocations from local governments which have an effect on financial distress (Madona, 2014).

On the basis of the above explanation, the research hypothesis can be formulated as follows:

H1 : The financial ratios has an effect on predicting inancial distress of local governments in Indonesia

$$
\operatorname{Ln} \frac{p}{1-p}=\beta_{0}+\beta_{1} X_{1}+\beta_{2} X_{2}+\beta_{3} X_{3} \ldots \ldots+\beta_{n} X_{n}+e
$$

H2: The local size has an effect on predicting financial distress of local governments in Indonesia

H3 : The local status has an effect on predicting financial distress of local governments in Indonesia

\section{RESEARCH METHODS}

\subsection{Samples and Data}

The sample used in this study is the local government in Indonesia, while the sampling technique is done by purposive sampling method, namely the sample is selected based on certain criteria as follows:

1) The Report on Local Government Finances of Indonesia issued in 20082014 and published on the Audit Board of the Republic of Indonesia(BPK RI) website, is www.bpk.go.id

2) The Report on Local Government Finances of Indonesia for 2008-2014 that report long-term debt and provide other financial information needed for measurement of research variables.

\subsection{Research Model}

The purpose of this study was to determine the effect of financial ratios, local size and local status on financial distress. To prove the hypotheses proposed in this study, the regression models in this study are as follows: 
International Journal of Economics, Business and Accounting Research (IJEBAR)

Peer Reviewed - International Journal

Vol-3, Issue-1, 2019 (IJEBAR)

ISSN: 2614-1280

http://www.jurnal.stie-aas/ijebar

Notes :

$\frac{p}{1-p}=$ The probability of financial distress of local government

$X_{1} \ldots . X_{n}=$ The financial ratio, local size, and local status

$\beta_{0} \ldots \ldots \beta_{n}=$ Regression coefficient

$\mathrm{E} \quad=$ Error

\subsection{Research Variables and Variable Measurement}

The following is explained about the operational definition and measurement of variables used in this study as follows:

\section{a. Dependent Variable}

In this study, the dependent variable is the probability of non-financial distress of local governments and financial distress of local governments indicated by the Debt Service Coverage Ratio (DSCR) as stipulated in government regulation No. 30 of 2011 concerning regional loans. Based on these regulations, DSCR can be written with the following formulas and conditions:

$$
D S C R=\frac{(P A D+B D+D A U)-B W}{P+B+B L}
$$

Notes :

$$
\begin{aligned}
\mathrm{DSCR}= & \text { Debt Service Coverage Ratio } \\
\mathrm{PAD}= & \text { Local Own-source Revenue } \\
\mathrm{BD}= & \text { Regional portion of land and } \\
& \text { building tax, fees for acquiring } \\
& \text { land and building rights, and } \\
& \text { receipt of natural resources, as } \\
& \text { well as other parts of the region } \\
& \text { such as from personal income } \\
& \text { tax. }
\end{aligned}
$$

DAU $=$ General Allocation Fund

$\mathrm{BW}=$ Mandatory expenditure is employee expenditure and expenditure of ocal legislative assembly (DPRD) members

$\mathrm{P}=$ Loan installments that are due in the relevant fiscal year

$\mathrm{B}=$ Loan interest expense

$\mathrm{BL}=$ Other costs include administrative fees, commitments, provisions, insurance and fines related to regional loans

Provisions for the feasibility of regional lending are Debt Service Coverage Ratio (DSCR) of at least 2.5 (two point five). For local governments that have DSCR value $<2.5$ (two point five), then it is declared experiencing financial distress and symbolized by number 0 , while for local governments that have DSCR> 2.5 (two point five) stated in non-financial distress conditions and symbolized by number 1 .

\section{b. Independent Variables}

The independent variable in this study consisted of financial and nonfinancial factors. Financial factors are represented by financial ratios adjusted to the data and information available in the Report on Local Government Finances. The financial ratios used are taken from the research of Cohen (2008), Trussel and Patrick (2009) and Cohen et al (2012) as follows:

1. Liquidity Ratio

a. Current ratio (CR)

2. Capital Structure Ratio

a. Debt to equity (D/E)

3. Performance Ratio 
International Journal of Economics, Business and Accounting Research (IJEBAR)

Peer Reviewed - International Journal

Vol-3, Issue-1, 2019 (IJEBAR)

ISSN: 2614-1280

http://www.jurnal.stie-aas/ijebar

a. Operating revenues to total revenues ratio (OR/TR)

4. Profitability Ratio

a. Return on assets ratio (ROA)

b. Return on equity ratio ( $\mathrm{ROE})$

5. Growth Ratio

a. Revenue growth (GROWTH)

Non-financial factors are represented by two macro-economic factors, are the local size and local status. Local size is measured using the population of a local government (POP). Whereas the local status (STATUS) which is the local government resulting from the expansion and nonexpansion is measured using the dummy variable, for the local government resulting from the expansion are symbolized by number 1 and for the local government of non-expansion symbolized by the number 0 .

\section{RESEARCH RESULTS AND DISCUSSION}

4.1 Research Results

\section{a. Sample Selection Results}

The population in this study is local government in Indonesia. The research sample was determined using a purposive sampling method with several provisions discussed earlier. After identification of 3563 Report on Local Government Finances (LKPD) in 2008-2014 issued by the Audit Board of the Republic of Indonesia, there are 2114 LKPDs that do not present longterm obligations and 808 LKPDs that do not provide complete data so that the results obtained are 641 LKPDs as the number of observations in the study.

\section{b. Descriptive Statistics}

Descriptive statistics provide an overview of the research data used in the study. The description in question includes the minimum value, maximum value, mean and standard deviation. The full description of this research data is presented in the following table.

Table 1

Descriptive Statistics

\begin{tabular}{llllll}
\hline Variabel & $\boldsymbol{N}$ & Minimum & Maximum & Mean & Std. Deviation \\
\hline CR & 641 & $-260,07$ & 12026,27 & 120,79 & 599,14 \\
D/E & 641 & $3,19 \mathrm{E}-06$ & 0,4816 & 0,0155 & 0,0273 \\
OR/TR & 641 & 0,0008 & 5,1268 & 0,1042 & 0,2127 \\
ROA & 641 & $-0,1278$ & 0,3163 & 0,0088 & 0,0287 \\
ROE & 641 & $-0,1650$ & 1,610 & 0,0117 & 0,0720 \\
GROWTH & 641 & $-0,5831$ & 27,54 & 0,2140 & 1,3151 \\
POP & 641 & 58068 & 3415700 & 730072,4 & 596671,6 \\
STATUS & 641 & 0 & 1 & 0,1342 & 0,3411 \\
Valid N & & & & & \\
(listwise) & 641 & & & &
\end{tabular}

Source: Eviews data processing, 2019

The table above shows the average value and standard deviation of the independent variables. In the liquidity ratio, the $\mathrm{CR}$ ratio has a minimum value of 260.07 , the maximum value is 12026.27 , the mean value is 120.79 and the standard 


\section{ISSN: 2614-1280}

http://www.jurnal.stie-aas/ijebar

deviation is 599.14. Based on these data, the standard deviation is greater than the mean value so there is a gap in the liquidity ratio.

Meanwhile, capital structure ratio which is proxied by the $\mathrm{D} / \mathrm{E}$ ratio has a minimum value of $3.19 \mathrm{E}-06$, the maximum value is 0.4816 , the mean value is 0.00155 and the standard deviation is 0.0273 . Based on these data, the standard deviation is greater than the mean value so that there is a gap in the capital structure ratio.

The performance ratio that is proxied by the OR/TR ratio has a minimum value of 0.0008 , the maximum value is 5.1268 , the mean value is 0.1042 and the standard deviation is 0.2127 . Based on these data, the standard deviation is greater than the mean value so there is a gap in the performance ratio.

In profitability ratios, ROA has a minimum value of -0.1278 , maximum value of 0.3163 , mean value of 0.0088 and standard deviation of 0.0287. Meanwhile, ROE has a minimum value of -0.1650 , a maximum value of 1.610 , an mean value of 0.0117 and a standard deviation of 0.0720 . Based on these data, the standard deviation is greater than the mean value so there is a gap in the profitability ratio.

The description of statistical data for growth ratios shows that the GROWTH ratio has a minimum value of -0.5831 , a maximum value of 27.54 , an mean value of 0.2140 and a standard deviation value of 1.3151. This figure shows the standard deviation is greater than the mean value so there is a gap in the growth ratio.

For non-financial factors, the POP variable has a minimum value of 58068, a maximum value of 3415700 , an mean value of 730072.4 and a standard deviation value of 596671.6. This number shows the standard deviation is smaller than the mean value so there is no gap from the population variable. Meanwhile, the STATUS variable has a minimum value of 0 , a maximum value of 1 , an mean value of 0.1342 and a standard deviation value of 0.3411 . This number shows the standard deviation is greater than the mean value so there is a gap from the status variable.

\section{c. Data Analysis}

Data analysis in this study used logistic regression with the help of computer software for Eviews version 9. This regression test overrides the assumptions of classical normality and assumptions such as heterocedasticity, autocorrelation and multicollinearity. The results obtained from the regression test indicate that the likelihood value based on the LR statistic value can be presented in the following table.

Table 2

Test of Likelihood Value

\begin{tabular}{ccc}
\hline Test of function (s) & LR Statistic & Prob. \\
\hline 1 & 77,142 & 0,000 \\
\hline
\end{tabular}

Source: Eviews data processing, 2019

The likelihood value indicates whether the addition of independent variables in the regression model can improve the regression model in predicting the dependent variable of the study. From table 2, the LR statistic value is 77.142 and 


\section{ISSN: 2614-1280}

http://www.jurnal.stie-aas/ijebar

the probability value is 0.000 which is smaller than the research significance level of $5 \%$, thus indicating that the addition of independent variables in the form of CR, D / E, OR / TR, ROA, ROE, GROWTH, POP and STATUS can be improve the fit model in the logistic regression model of this study.

In addition, the results of the logistic regression analysis also indicated the fit of the tested model based on the values of Hosmer and Lemeshow's Goodness of Fit Test. If the HL Goodness-of-fit statistic value is greater than the research significance level of $5 \%$, then the null hypothesis cannot be rejected and means the model is able to predict its observations or it can be said that the model is acceptable because it matches the observational data (Ghozali and Ratmono, 2013: 344). The HL statistics value is 9.3779 with a significance probability of 0.3114 whose value is above $5 \%$. Thus it can be concluded that the regression model used in this study is fit (fit) to be used. The full value of Hosmer and Lemeshow's Goodness of Fit Test can be seen in the following table.

Table 3

Test the Hosmer and Lemeshow's Value Goodness of Fit Test

\begin{tabular}{cccc}
\hline Test of function (s) & HL Statistic & df & Prob. \\
\hline 1 & 9,3779 & 8 & 0,3114 \\
\hline
\end{tabular}

Source: Eviews data processing, 2019

The results of the regression analysis also show the value of McFadden R-squared which is an analogous measure with $\mathrm{R}^{2}$ in the regression of Ordinary Least Square (Ghozali and Ratmono, 2013: 344). McFadden $\mathrm{R}$-squared value explains how much the independent variable is able to explain the influence on the dependent variable. The results of the McFadden Rsquared value test of this study were 0.403 which means that the variability of the dependent variable in this case financial distress and non financial distress can be explained by the independent variables $\mathrm{CR}$, D / E, OR / TR, ROA, ROE, GROWTH, POP and STATUS of $40.3 \%$. While the remaining $59.7 \%$ is explained by other variables not included in this study.

To strengthen the results of the analysis, it was also used percently correctly predicted. The greater the value of the predicted percentage, the better the model (Ghozali and Ratmono, 2013: 344). Complete precently correctly predicted values can be seen in the following table. 
International Journal of Economics, Business and Accounting Research (IJEBAR)

Peer Reviewed - International Journal

Vol-3, Issue-1, 2019 (IJEBAR)

ISSN: 2614-1280

http://www.jurnal.stie-aas/ijebar

Table 4

Expectation-Prediction Evaluation for Binary Specification

\begin{tabular}{|c|c|c|c|}
\hline \multirow{2}{*}{} & \multicolumn{2}{|c|}{ Estimated Equation } & \multirow{2}{*}{ Total } \\
\cline { 2 - 3 } & Dep $=\mathbf{0}$ & Dep $=\mathbf{1}$ & \\
\hline $\mathrm{P}($ Dep=1 $)<=\mathrm{C}$ & 5 & 3 & 8 \\
$\mathrm{P}(\mathrm{Dep}=1)>\mathrm{C}$ & 17 & 616 & 633 \\
Total & 22 & 619 & 641 \\
Correct & 5 & 616 & 621 \\
\%Correct & 22,73 & 99,52 & 96,88 \\
\%Incorrect & 77,27 & 0,48 & 3,12 \\
\hline \multicolumn{2}{|c|}{ O Financial Distress, I = Non Financial Distress }
\end{tabular}

Source: Eviews data processing, 2019

The results of testing this study in the table above shows that overall prediction accuracy reaches $96.88 \%$ so it can be concluded that the model is quite good.

Table 5

Logistic Regression Test Results

\begin{tabular}{lllll}
\hline \hline Variable & Coefficient & Std. Error & z-Statistic & Prob. \\
\hline \hline CR & 0.0233 & 0.0098 & 2.3763 & $0.0175^{* *}$ \\
D/E & -41.557 & 9.4313 & -4.4063 & $0.0000^{*}$ \\
OR/TR & 18.2602 & 8.0863 & 2.2582 & $0.0239^{*} *$ \\
ROA & -43.6406 & 9.3914 & -4.6469 & $0.0000^{*}$ \\
ROE & 11.6780 & 4.8340 & 2.4158 & $0.0157^{*}$ \\
GROWTH & 3.8028 & 2.4127 & 1.5761 & 0.1150 \\
POP & $1.54 \mathrm{E}-06$ & $8.89 \mathrm{E}-07$ & 1.7274 & $0.0841^{*} *$ \\
STATUS & 1.7123 & 0.8588 & 1.9938 & $0.0462^{*} *$ \\
\hline \hline
\end{tabular}

*significant at $\alpha=1 \%, * *$ significant at $\alpha=5 \%, * * *$ significant at $\alpha=10 \%$

$\mathrm{CR}$ : current ratio, $\mathrm{D} / \mathrm{E}:$ debt to equity ratio, $\mathrm{OR} / \mathrm{TR}$ : operating revenues to total revenues ratio, $\mathrm{ROA}$ : return on assets ratio, $\mathrm{ROE}$ : return on equity ratio, GROWTH : revenue growth ratio, POP : population, STATUS : regional expansion

Source: Eviews data processing, 2019

\subsection{DISCUSSION}

\section{a. Effect of Financial Ratio on Financial} Distress

The test results as presented in table 5 show that of the 6 ratios, it is proven that 5 ratios are $\mathrm{CR}, \mathrm{D} / \mathrm{E}, \mathrm{OR} / \mathrm{TR}, \mathrm{ROA}$, and $\mathrm{ROE}$ had a probability value smaller than the research significance level of $1 \%, 5 \%$, and $10 \%$ so that it can be said that these variables affect the financial distress of local 


\section{ISSN: 2614-1280}

http://www.jurnal.stie-aas/ijebar

governments in Indonesia. The status of financial distress is the inability of the local government to repay loan principal and loan interest. The results of this study support the empirical evidence of previous studies (Trussel and Patrick, 2009; Sutaryo, 2009; Sutaryo et al., 2012) that financial ratios compiled based on information from report on local government finances can be used to predict financial distress. The prediction of financial distress of a local government is very beneficial for the sustainability of regional finance in the future. The earlier knowing that local governments are in the status of financial distress, the better for local management because they can take preventive measures quickly and right before the failure.

\section{b. Effect of Local Size on Financial Distress}

Population is usually used as a proxy for local size. In table 5 shows that the POP variable has a significance value of 0.0841 which is smaller than the research significance level of $1 \%$ so that the population influences the financial distress. Positive coefficient values indicate that when the population of a local government increases, the problem of bureaucracy in government becomes more intense and operational implementation and management of resources become less efficient so that they cannot meet public service needs adequately (Cohen, 2008). The results of this study are in line with Jones and Walker (2007) that local governments that are unable to provide services to the public in accordance with established quality standards will experience financial distress.

\section{c. Effect of Local Status on Financial Distress}

The local status is illustrated by the phenomenon of regional expansion in Indonesia. In table 5 shows that the STATUS variable has a significance value of 0.0462 which is smaller than the research significance level of $5 \%$ so that the local status affects financial distress. The results of this study are in line with Syurmita (2014) that new autonomous regions that experience expansion tend to experience financial distress. This is because the capacity of regions that are divided in managing local finances is not optimal (Madona, 2014). According to the study FITRA (Indonesian Forum for Budget Transparency), motivated the birth of a new area to take a bigger budget. The General Allocation Fund (DAU) formula that includes employees expenditure as a basic allocation motivates regions to swell employee spending. It is also motivated to do the expansion region for employees expenditure burden is bound to be financed by the DAU. Therefore motivation more in the nature of the politician, the new autonomous regions have worse performance than the autonomous region's long-standing. Based on the results of the performance evaluation of a new autonomous region in 2014 by the Ministry of Home Affairs said only $58.71 \%$ of high performers. In addition, other facts show that there are 34 regions are being left behind or poor after bloomed. 
Vol-3, Issue-1, 2019 (IJEBAR)

ISSN: 2614-1280

http://www.jurnal.stie-aas/ijebar

\section{CONCLUSION, LIMITATIONS AND RECOMMENDATION}

\subsection{Conclusion}

This study aims to find out and analyze whether financial ratios, regional size and regional status influence the financial distress of local governments. The sample in this study is the district / city local government in Indonesia that publishes report on local government finances in 2008-2014 at the Audit Board of the Republic of Indonesia webiste.

This study proves that the financial ratios of the financial statements of local government is able to predict the financial distress of the local government in Indonesia. These conclusions are based on test results from the logistic regression model of research that indicates that the variable $\mathrm{CR}, \mathrm{D} / \mathrm{E}, \mathrm{OR} / \mathrm{TR}, \mathrm{ROA}$ and $\mathrm{ROE}$ affect the financial distress of the local government in Indonesia with years of observations from 2008 to 2014. On the basis of these results, it can be stated that the $\mathrm{CR}, \mathrm{D} / \mathrm{E}, \mathrm{OR} / \mathrm{TR}, \mathrm{ROA}$ and ROE are financial variables that affect the financial distress of the local government in Indonesia. While the GROWTH variable is not a financial variable that affect the financial distress of local governments in Indonesia.

In addition, this study also proved that the non-financial variables are also able to predict the financial distress of the local government in Indonesia. This conclusion is based on the results of testing the research model with logistic regression which shows that the POPULATION and STATUS variables affect the financial distress of local governments in Indonesia. Thus, it can be stated that the POPULATION and STATUS variables are non-financial variables that affect the financial distress of local governments in Indonesia.

\subsection{Limitations}

The author realizes that this study has several limitations that might influence the results of the study. The limitations are as follows:

1. The value of McFadden R-squared in this study is 0.403 which means that the dependent variable is explained by the independent variable only $40.3 \%$. While the remaining $59.3 \%$ is explained by other variables not included in the study.

2. Does not issue a Report on Local Government Finances with adverse and disclaimer opinions from the research sample because it has poor quality financial information.

3. Does not distinguish samples based on certain criteria such as the geographical location of local governments that can influence the results of research.

\subsection{Recommendation}

To be able to develop the results of further research, the next study is suggested to be able to complement the limitations of this study, are :

1) Adding other independent variables that are considered to have the potential to influence research results such as Local Gross Domestic Product (PDB) or political parties.

2) Only use Report on Local Government Finances with opinions that guarantee the quality of information provided 
International Journal of Economics, Business and Accounting Research (IJEBAR)

Peer Reviewed - International Journal

Vol-3, Issue-1, 2019 (IJEBAR)

ISSN: 2614-1280

http://www.jurnal.stie-aas/ijebar

3) Distinguish samples based on the geographical location of the local government

\section{REFERENCES}

ACIR. 1985. The States and Distressed Communities: The Final Report. Washington D.C

Almilia, Luciana Spica dan Kristijadi. 2003. Analisis Rasio Keuangan untuk Memprediksi Kondisi Financial Distress Perusahaan Manufaktur yang Terdaftar di Bursa Efek Jakarta. JAAI. Vol. 7, No. 2 page 63-77

Amendola, Alessandra, Marialuisa Restaino, dan Luca Sensini. 2015. An Analysis of the Determinants of Financial Distress in Italy: A Competing Risk Approach. International Review of Economic and Finance. Vol. 37, page 33-41

Beaver, William H. 1966. Financial Ratios as Predictors of Failure. Journal of Accounting Research. Page 71-111

Cohen, Sandra. 2008. Identifying the Moderator Factors of Financial Performance in Greek Municipalities. Financial Accountability \& Management. 24 (3), 267-4424

, Michael Doumpos, Evi Neofytou dan Constantin Zoppounidis. 2012. Assesing Financial Distess Where Banckruptcy is Not An Option: An Alternative Approach for Local Municipalities. European Journal of Operational Research. page 270-279

Ghozali, Imam dan Dwi Ratmono. 2013. Analisis Multivariate dan

Ekonometirka : Teori, Konsep dan Aplikasi dengan EVIEWS 8. Semarang: Badan Penerbit Universitas Diponegoro

Habib, Ahsan., Md. Borhan Uddin Bhuiyan dan Ainul Islam. 2013. Financial Distress, Earning Management and Market Pricing of Accrual During the Global Financial Crisis. Managerial Finance. Vol. 39, No. 2 page $155-180$

Halim, Abdul. 2007. Akuntansi Sektor Publik : Akuntansi Keuangan Daerah. Edisi 3. Jakarta: Salemba Empat

Hanafi, Mamduh M dan Abdul Halim. 2016. Analisis Laporan Keuangan. Edisi 5. Yogyakarta: UPP STIM YKPN

Jones, Stewart dan R.G. Walker. 2007. Explanators of Local Government Distress. ABACUS. Vol. 43, No. 3 page 396-417

Kieso, Donald E., Jerry J. Weygandt dan Terry D. Warfield. 2008. Akuntansi Intermediate. Edisi ke-12, Jilid 1. Jakarta : Erlangga

Liao, Xinxin dan Yunguo Liu. 2014. Local Fiscal Distress and Investment Efficiency of Local SOEs. China Journal of Accounting Research. Vol. 7, page 119-147

Madona, Wenny Safitri. 2014. Pengaruh Karakteristik Keuangan Pemerintah Daerah Terhadap Belanja Operasi Pada Pemerintah Daerah Kabupaten/Kota yang mengalami Pemekaran. Tesis Universitas Sebelas Maret

Pasaribu, Rowland Bismark Fernando. 2008. Penggunaan Binary Logit untuk Prediksi Financial Distress 
International Journal of Economics, Business and Accounting Research (IJEBAR)

Peer Reviewed - International Journal

Vol-3, Issue-1, 2019 (IJEBAR)

ISSN: 2614-1280

http://www.jurnal.stie-aas/ijebar

Perusahaan yang Tercatat di Bursa Efek Jakarta (Studi Kasus Emiten Industri Perdagangan). Jurnal Ekonomi Bisnis \& Akuntansi Ventura. Vol. 11, No. 2

Peraturan Pemerintah Republik Indonesia Nomor 30 Tahun 2011 tentang Pinjaman Daerah

Plat, Harlan D. dan Marjorie B. Plat. 2002. Predicting Corporate Financial Distress: Reflections on ChoiceBased Sample Bias. Journal of Economics and Finance. Vol 26, No.

2, page 184-199

SEKNAS FITRA. 2011. Moratorium

Belanja Pegawai. Diakses tanggal 30 Juli 2016.

http://seknasfitra.org/moratorium-

belanja-pegawai-2/

SEKNAS FITRA. 2012. Birokrasi

Tambun"; 291 Daerah Habiskan Separuh Lebih APBD untuk Belanja Pegawai. Diakses tanggal 30 Juli 2016.

http://seknasfitra.org/pressrelease/bi rokrasi-tambun-291-daerah-

habiskan-separuh-lebih-apbd-untukbelanja-pegawail

SEKNAS FITRA. 2014. Pemekaran (Masalah) Daerah. Diakses tanggal $11 \quad$ Februari 2019. http://seknasfitra.org/pemekaranmasalah-daerah/

Surtikanti. 2013. Permasalahan Otonomi Daerah Ditinjau dari Aspek Perimbangan Keuangan Pemerintah Pusat dan Daerah. Majalah Ilmiah UNIKOM. Vol. 11, No.1

Sutaryo. 2009. Nilai Relevan Informasi Laporan Keuangan Pemerintah Daerah di Indonesia. Tesis Universitas Sebelas Maret Surakarta Ramawati. 2012. Relevansi Informasi Laporan Keuangan Cash Modified Basis : Kemampuan Rasio Keuangan dalam Memprediksi Status Financial Distress Pemerintah Daerah di Indonesia. Simposium Nasional Akuntansi XV. Banjarmasin, 20-23 September

Syurmita. 2014. Prediksi Financial Distress Pemerintah Daerah Kabupaten/Kota di Indonesia. Simposium Nasional Akuntansi XVII. Mataram, 24-27 September

Trussel, John M dan Patricia A. Patrick. 2009. A Predictive Model of Fiscal Distress in Local Governments. Journal of Public Budgeting, Accounting \& Financial Management. 21 (4), page 578-616 Undang-Undang Republik Indonesia Nomor 32 Tahun 2004 tentang Pemerintahan Daerah

www.bps.go.id diakses pada tanggal 5 Januari 2016 pukul 11.00 WIB

Xie, Chi., Changqing Luo dan Xiang Yu. 2011. Financial Distress Prediction Based on SVM and MDA Methods: The Case of Chinese Listed Companies. Quality \& Quantity. 45 (3), page 671-686 